Gangolells M., Casals M., Forcada N., Fuertes A. Roca X. Model for enhancing integrated identification, assessment and operational control of on-site environmental impacts and health and safety risks in construction firms. Journal of Construction Engineering and Management, 2013, 139(2): 138-147. < doi: 10.1061/(ASCE)CO.1943-7862.0000579>.

Final version available at: $\quad$ http://ascelibrary.org/doi/abs/10.1061/\%28ASCE\%29CO.19437862.0000579>.

\title{
Model for enhancing integrated identification, assessment and operational control of on-site environmental impacts and health and safety risks in construction firms
}

\author{
Marta Gangolells ${ }^{1}$, Miquel Casals ${ }^{2}$, Nuria Forcada ${ }^{3}$, Alba Fuertes ${ }^{4}$, Xavier Roca $^{5}$
}

${ }^{1}$ Lecturer, Department of Construction Engineering, Technical University of Catalonia (UPC), C/ Colom, 11, Ed. TR5, 08222 Terrassa (Barcelona), Spain (corresponding author). Tel: (+34) 93 7398947, Fax: (+34) 93 7398670, E-mail: marta.gangolells@upc.edu

${ }^{2}$ Associate Professor, Department of Construction Engineering, Technical University of Catalonia (UPC), C/ Colom, 11,Ed. TR5, 08222 Terrassa (Barcelona), Spain. E-mail: miquel.casals@upc.edu

${ }^{3}$ Associate Professor, Department of Construction Engineering, Technical University of Catalonia (UPC), C/ Colom, 11, Ed. TR5, 08222 Terrassa (Barcelona), Spain (corresponding author). Tel: (+34) 93 7398947, Fax: (+34) 93 7398670, E-mail: nuria.forcada@upc.edu

${ }^{4}$ Assistant Lecturer, Department of Construction Engineering, Technical University of Catalonia (UPC), C/ Colom, 11, Ed. TR5, 08222 Terrassa (Barcelona), Spain. E-mail: alba.fuertes@upc.edu

${ }^{5}$ Associate Professor, Department of Construction Engineering, Technical University of Catalonia (UPC), C/ Colom, 11, Ed. TR5, 08222 Terrassa (Barcelona), Spain (corresponding author). Tel: (+34) 93 7398947, Fax: (+34) 93 7398670, E-mail: xavier.roca@upc.edu

\section{ABSTRACT}

Certifiable management system standards apply similar management techniques and principles, but each system still tends to have a separate structure in construction companies. Research and practice have demonstrated that management tasks may be duplicated when standards are implemented in parallel. Consequently, integrated management systems are strongly advocated. However, existing literature demonstrates that the integration of planning and control instruments involves a high level of uncertainty. We present an innovative model to enhance the integration of environmental and health and safety management systems in construction companies, focusing on the sub-systems for identifying, assessing and operationally controlling environmental aspects and health and safety hazards and using risk as an integrating factor. The findings of this study have direct implications for both designers and contractors as the model helps to explicitly consider on-site environmental impacts and construction worker safety during the design process and offers on-site guidance to eliminate the remaining impacts and risks or reduce them to an acceptable level. A case study is reported to illustrate the practical use of the proposed model and its benefits. 
CE Database subject headings:

integrated systems, systems management, environmental issues, safety, construction companies

Author keywords:

integrated management systems, environmental management, health and safety management, construction process

\section{INTRODUCTION}

Although quality management systems have been successfully implemented by contractors over the last 25 years (Griffith and Bhutto, 2008a), environmental management systems are less common in construction companies. The two main environmental management certification schemes are the European-wide EcoManagement and Audit Scheme (EMAS) and the worldwide ISO 14001. While 76,043 construction companies had quality certificates in 2008 (ISO Central Secretariat, 2009), only 9,696 had received ISO 14001 certificates by the end of the same year (ISO Central Secretariat, 2009) and just 214 had adopted and implemented EMAS (European Commission, 2010). The implementation of occupational health and safety management systems is even lower within the construction sector, although this is statistically one of the most hazardous industries in many countries (Carter and Smith, 2006; Wang et al., 2006; Camino et al., 2008) and it is widely recognized that safety management systems significantly contribute to lower injury rates (Koehn and Datta, 2003). Driven by the British Standards Institution (BSI), OHSAS 18001 is used as the basis for certification of occupational health and safety management systems. In addition to general implementation barriers that may affect all sectors, some authors have suggested that the inherent peculiarities of the construction industry (including the uniqueness of projects, the high variability in construction techniques and systems, the geographic dispersion of production sites, and the temporary nature of construction projects) hamper the implementation of management systems in contractor companies (Bhutto et al., 2004; Piñeiro and García, 2007). Research has demonstrated that the implementation and operation of standards in parallel leads to the duplication of many management tasks (Zeng et al., 2007; Labodová, 2004). Hence, integrated management systems have been strongly advocated. The literature indicates that some elements, such as structure, size and economic sector, may play a decisive role in influencing whether an organization decides to integrate systems and the breadth or depth of integration (Jørgensen et al., 2006; Salomone, 2008). Research conducted to date reveals a significant lack of case studies on the implementation of integrated management systems in construction companies, especially when safety management systems are included (Griffith and Bhutto, 2008b). It was generally found that companies integrate their management systems at alignment level (Jørgensen et al., 2006; Karapetrovic, 2002; Pheng and Tan, 2005; Zutshi, 2005; Zeng et al., 2008) by combining documentation, although the integration of these management systems into an 'all-inone' system (Karapetrovic, 2002) is more desirable. A review of relevant literature in this field, including papers by Zeng et al. (2007); Jørgensen et al. (2006); Salomone (2008); Pheng and Tan (2005); Zutshi (2005); Zeng et al. (2008); Pheng and Pong 
(2003); Zeng and Tian (2005); Pheng and Kwang (2005), revealed a number of quantifiable and unquantifiable benefits for companies that operate an integrated management system. However, to attain these benefits, organizations must be aware of the challenges and obstacles involved in the process of integrating standards. According to Griffith and Bhutto (2008a), the most common obstacles relate to a lack of understanding of how best to integrate the different management systems. Other problems that are frequently cited in the literature are a lack of qualified personnel to cover all system requirements and a lack of technical guidance and support from certification bodies. Previous research states that planning and control instruments are the areas that are least commonly integrated in companies. In a survey conducted by Pheng and Shiua (2000), over $80 \%$ of the respondents did not find it easy to integrate elements for identifying and assessing risks and for implementing the necessary control measures or they did not indicate whether integration would be possible. The empirical results of a study by Salomone (2008) also corroborate these findings.

The purpose of this paper is to enhance the process of implementing integrated environmental and safety management systems in construction companies by addressing the shortcomings outlined above. We focus particularly on the lack of understanding of how best to integrate different management systems during planning for risk identification, assessment and control. Therefore, the aim of this paper is to develop a model to improve the systematic identification, assessment and operational control of environmental impacts and health and safety risks in construction companies and residential construction projects.

Following this introduction, the second section reports relevant research work. The third section presents the conceptual framework for the integrated identification, assessment and operational control of environmental impacts and health and safety risks related to the process of constructing residential buildings. The fourth section reports the validation of the model. A case study illustrates a practical application of the model and demonstrates how environmental and health and safety elements can be intrinsically adopted as part of project design, planning and construction. The final section discusses the conclusions and the future research issues.

\section{EXISTING APPROACHES}

No relevant approaches for integrating the identification, assessment and operational control of environmental impacts and health and safety risks in construction projects and construction sites were found in the literature. Relevant research on addressing potential on-site environmental impacts and construction workers' safety in the design and construction planning stages is reported in this section.

Building designers are not legally required to consider the potential on-site environmental impact of their designs, as residential construction projects are hardly ever subjected to the Environmental Impact Assessment Directive (Gangolells et al., 2011). Even building environmental assessment methods, which are based on the concept of Life Cycle Assessment, do not offer proper coverage to the execution phase. Bunz et al. (2006) compared and contrasted 10 building environmental assessment 
methods. According to Bunz et al. (2006), two of them do not provide recommendations for the building construction phase, whereas the other only include waste management, the transportation of building materials, and the impact of construction activities on the work site and surroundings. It is recognized in the literature that contractors need a proper design for eliminating and/or reducing environmental hazards to improve environmental management (Trethewy et al., 2003; Eom and Paek, 2009). However, no practical and consistent approaches have been found outside of this research. According to Chen and Li (2006), only a few research projects specifically analyse the integration of environmental management aspects into the construction planning stage and their approaches are highly qualitative. Of the papers that describe such methods, the approaches of Eom and Paek (2009), Tam et al. (2004), Shen et al. (2005), Li et al. (2005), Cheung et al. (2004b), Tam et al. (2006), Chen et al. (2000), Chen et al. (2004) and Chen et al. (2005) are noteworthy. However, some of these methods assess the impact of construction in terms of the presence or absence of environmental protocols. In other cases, the selection of environmental impacts is arbitrary and incomplete. In addition, some methods exclude context-related issues such as site selection and building location and, in general, subjective judgements influence their accuracy. Despite these studies, a survey by Dione et al. (2005) showed that many construction companies are concerned about the possible implications of environmental risks to their projects. However, there still needs to be more emphasis on the identification and mitigation of such risks.

Although regulations oblige designers to address safety during the construction phase, they often include generic risk assessments (Baxendale and Jones, 2000) and a collection of generic prevention measures that clearly diminish effectiveness. In recent years, academics and professionals have focused on the concept of Construction Hazard Prevention through Design (CHPtD). The approaches of Imriyas (2009), Seo and Choi (2008) and Frijters and Swuste (2008) are notable. However, in some cases, subjective judgements influence their accuracy. Therefore, additional tools and processes are needed to assist architects and design engineers with hazard recognition and design optimization (Gambatese, 2008). As in the design stage, current legal approaches to planning for health and safety in the construction industry have been criticized for being bureaucratic and irrelevant (Cameron and Hare, 2008). The empirical results of Carter and Smith (2006) indicate that hazard identification levels are far from ideal. The main barriers to improvement in this key area include a lack of resources and the knowledge or willingness to adequately identify hazards in a formal (documented) way (Trethewy et al., 2003). Although some authors have addressed worker safety in the construction planning stage (Saurin et al., 2004; Carter and Smith, 2001; Wang et al., 2006; Cheung et al., 2004a), hazard identification and risk assessment are still highly subjective and their usefulness and effectiveness is therefore limited.

\section{METHOD}

According to Griffith (2011), risk management is an essential element of all management systems and should form the central feature of an integrated management system. In addition, a thorough review of ISO 14001:2004 and OHSAS 18001:2007 revealed that risk management processes (risk identification, risk assessment, and risk 
control) are identical in the environmental and the health and safety domains. Thus, we used risk as an integrating factor in this method. In fact, the notion of injury equally applies to damage to the life and health of employees, the surrounding population, and the environment.

Figure 1 summarizes the general requirements for an integrated environmental and health and safety management system. The main steps defined for the integrated identification of environmental impacts and health and safety risks related to the construction process are (1) inventory of construction processes, activities and stages, (2) inventory of environmental aspects, (3) inventory of health and safety risks, and (4) determination of the significance of environmental impacts and health and safety risks in a particular construction stage. The main steps required for the integrated assessment of environmental impacts and health and safety risks at the pre-construction stage are (1) development of indicators, (2) formulation of significance limits and (3) determination of the significance of the environmental impacts and health and safety risks of a construction project.

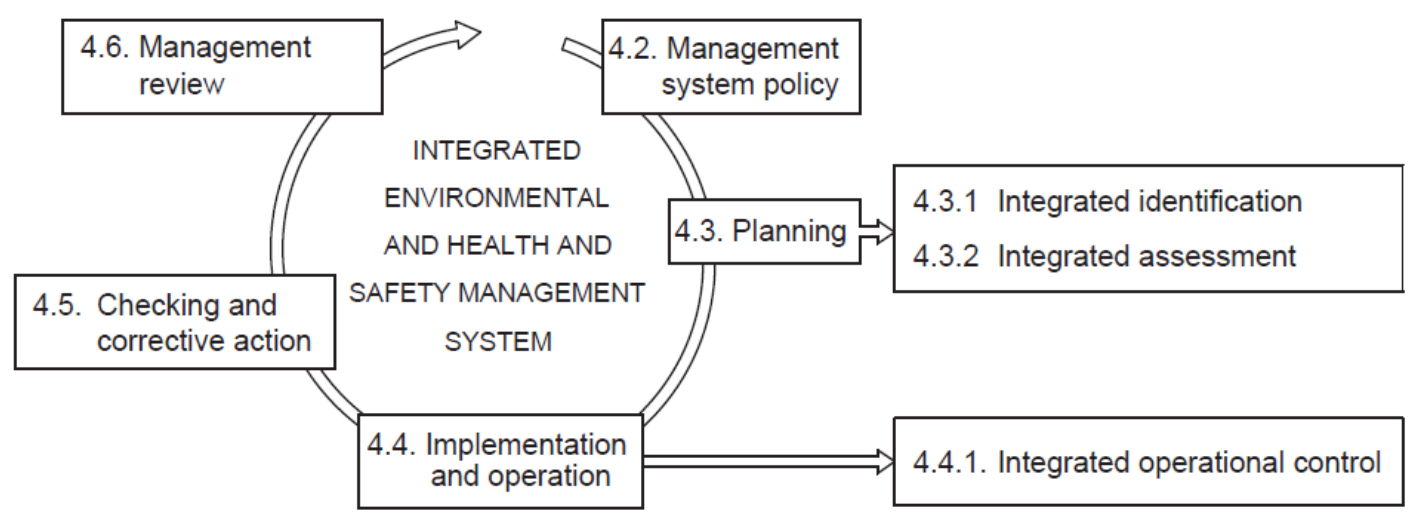

Figure 1. General requirements for an integrated environmental and health and safety management system and research methodology. Source: partially adapted from

OHSAS 18001:2007 and ISO 9001:2008.

\subsection{INTEGRATED IDENTIFICATION}

To identify environmental aspects and health and safety risks that are related to the construction of residential buildings, we carried out an exhaustive preliminary analysis with a process-oriented approach (Gangolells et al., 2009; Gangolells et al., 2010). Firstly, the main processes were identified, according to the work sections in the MetaBase database (ITeC, 2006), and divided into smaller process steps (Roberts and Robinson, 1998). A total of 219 stages and activities were considered. Secondly, generic environmental aspects and health and safety risks were identified. EMAS was used as a guide to initially identify environmental aspects (Gangolells et al., 2009) and the Occupational Accident Report Form of the Spanish National Institute of Safety and Hygiene at Work was used for the health and safety risks (Gangolells et al., 2010). 
Thirdly, we analysed the criteria for significance established in ISO 14004:2004, OHSAS 18001:2007 and related literature. Some of these criteria were found to be directly related to construction stages and activities, but were not dependant on the specific characteristics of the construction project (Gangolells et al., 2009; Gangolells et al., 2010). Such criteria were used in this early stage to determine significant environmental aspects and health and safety risks for each construction process (Figure $2)$. The generic environmental aspects that were initially considered were evaluated in terms of scale $\left(\mathrm{S}_{\mathrm{i}}\right)$, duration $\left(\mathrm{D}_{\mathrm{i}}\right)$ and probability of occurrence $\left(\mathrm{P}_{\mathrm{i}}\right)$ for each construction stage i (Gangolells et al., 2009) by calculating the environmental impact degree (ID Ei $_{\text {) }}$ (Figure 2). The generic health and safety risks that were initially considered were evaluated in terms of probability of occurrence $\left(\mathrm{P}_{\mathrm{i}}\right)$ and severity of consequences $\left(\mathrm{C}_{\mathrm{i}}\right)$ for each construction stage i (Gangolells et al., 2010) by calculating the safety risk degree $\left(\mathrm{RD}_{\mathrm{Si}}\right)$ (Figure 2). To reduce subjectivity during the identification of environmental aspects and health and safety risks related to the construction process, we developed a four-point scale and gave corresponding numerical scores to each component of significance (Table 1 and Figure 2). 

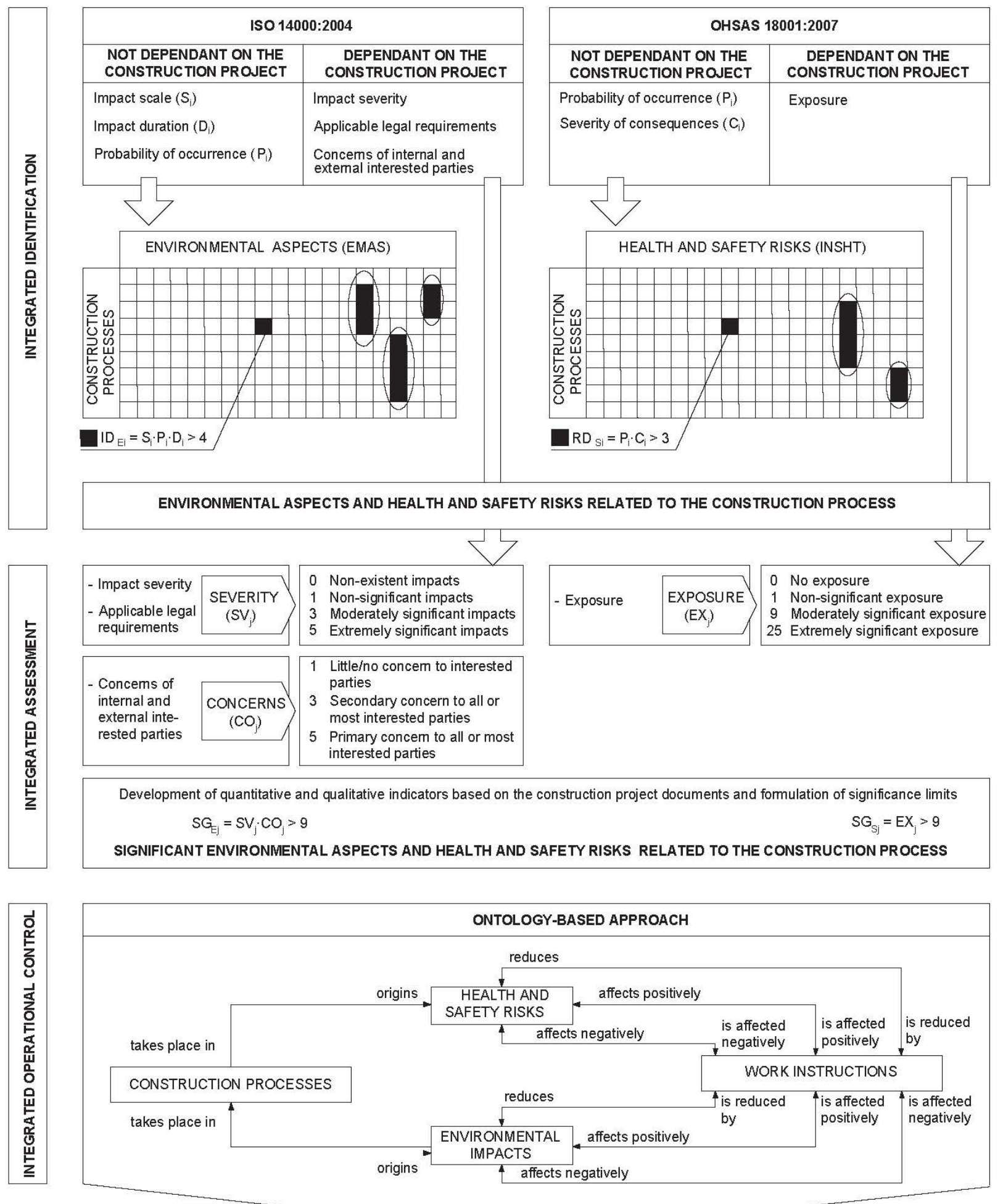

Figure 2. Framework for the integrated identification, assessment and operational control of environmental impacts and health and safety risks. 


\begin{tabular}{|c|c|c|c|c|c|}
\hline & \multicolumn{3}{|c|}{ ENVIRONMENTAL DOMAIN } & \multicolumn{2}{|c|}{$\begin{array}{c}\text { HEALTH AND SAFETY } \\
\text { DOMAIN }\end{array}$} \\
\hline Score & $\begin{array}{c}\text { Impact scale } \\
\left(\mathrm{S}_{\mathrm{i}}\right)\end{array}$ & $\begin{array}{l}\text { Probability of } \\
\text { occurrence }\left(\mathbf{P}_{\mathrm{i}}\right)\end{array}$ & $\begin{array}{c}\text { Impact } \\
\text { duration }\left(D_{i}\right)\end{array}$ & $\begin{array}{l}\text { Probability of } \\
\text { occurrence }\left(\mathbf{P}_{\mathrm{i}}\right)\end{array}$ & $\begin{array}{c}\text { Severity of } \\
\text { Consequences } \\
\left(\mathrm{C}_{\mathrm{i}}\right)\end{array}$ \\
\hline 0 & None & Improbable & None & Improbable & None \\
\hline 1 & $\begin{array}{l}\text { Site and } \\
\text { surrounding } \\
\text { area }\end{array}$ & Not very likely & $\begin{array}{l}\text { Less than the } \\
\text { work phase }\end{array}$ & Not very likely & Minor \\
\hline 3 & $\begin{array}{l}\text { Local and } \\
\text { regional }\end{array}$ & Likely & $\begin{array}{l}\text { Equal to the } \\
\text { work phase }\end{array}$ & Likely & Major \\
\hline 5 & Out of region & Very likely & $\begin{array}{l}\text { More than the } \\
\text { work phase }\end{array}$ & Very likely & Catastrophic \\
\hline
\end{tabular}

Table 1. Scoring system for the components of significance in the environmental and the health and safety domains.

During this initial review, an environmental impact was considered significant in a specific construction stage if its degree was greater than 4 and a health and safety risk was considered significant in a specific construction stage when its degree was greater than 3 (Figure 2). The resulting matrix allowed us to distinguish 30 significant environmental impacts (Gangolells et al., 2009) and 84 significant health and safety risks for construction activities (Gangolells et al., 2010). Some of the risks apply to both the environmental and health and safety domains. For example, the generation of noise and vibrations due to site activities is classified in the environmental category of 'local issues' and in the safety category of 'contact with physical agents'.

\subsection{INTEGRATED ASSESSMENT}

We used the remaining components of significance, which were those that depended on each construction project, to assess environmental aspects and health and safety risks at the pre-construction stage (Figure 2). The severity parameter (SV) estimates the magnitude (or relevance) of each environmental aspect in quantitative terms (Gangolells et al., 2009). The concerns parameter (CO) includes the concerns of neighbouring communities that would be directly affected by a proposed project and those of society as a whole (Gangolells et al., 2011). The exposure parameter (EX) is a quantitative or semi-quantitative estimation of potentially hazardous situations to which workers are exposed during on-site construction (Gangolells et al., 2010) (Figure 2).We developed a four-point scale that includes detailed criteria to help determine whether these parameters are significant (Gangolells et al., 2011; Gangolells et al., 2009; Gangolells et al., 2010) and numerical limits were established between the four categories (Figure 2 and Table 2). 


\begin{tabular}{|c|c|c|c|c|c|c|c|}
\hline \multicolumn{2}{|l|}{ RISK } & \multicolumn{4}{|c|}{ SEVERITY (SV) / EXPOSURE (EX) } & \multicolumn{2}{|c|}{ CONCERNS (CO) } \\
\hline Code & Description & Value & Indicator & $\begin{array}{l}\text { Building } \\
\text { typology }\end{array}$ & Numerical limits & Value & Indicator \\
\hline \multirow{4}{*}{$\mathrm{RC}-1$} & \multirow{4}{*}{$\begin{array}{l}\text { Water } \\
\text { consumption } \\
\text { during the } \\
\text { construction } \\
\text { process. }\end{array}$} & $\mathrm{SV}=0$ & \multirow{4}{*}{$\begin{array}{l}\text { Water } \\
\text { consumption }{ }^{1} \\
\text { per } \mathrm{m}^{2} \text { of floor } \\
\text { area }\left(\mathrm{m}^{3} / \mathrm{m}^{2}\right)\end{array}$} & $\begin{array}{l}\mathrm{SF} \\
\mathrm{MF}\end{array}$ & - & $\mathrm{CO}=0$ & - \\
\hline & & $\mathrm{SV}=1$ & & $\begin{array}{l}\mathrm{SF} \\
\mathrm{MF}\end{array}$ & $\begin{array}{l}\mathrm{P}<0.0592 \\
\mathrm{P}<0.0606\end{array}$ & $\mathrm{CO}=1$ & Use of rainwater or tap water. \\
\hline & & $\mathrm{SV}=3$ & & $\begin{array}{l}\mathrm{SF} \\
\mathrm{MF}\end{array}$ & $\begin{array}{l}0.0592 \leq \mathrm{P}<0.1272 \\
0.0606 \leq \mathrm{P}<0.0974\end{array}$ & $\mathrm{CO}=3$ & $\begin{array}{l}\text { Use of water tankers or water } \\
\text { from rivers or wells. }\end{array}$ \\
\hline & & $\mathrm{SV}=5$ & & $\begin{array}{l}\mathrm{SF} \\
\mathrm{MF}\end{array}$ & $\begin{array}{l}\mathrm{P} \geq 0.1272 \\
\mathrm{P} \geq 0.0974\end{array}$ & $\mathrm{CO}=5$ & $\begin{array}{l}\text { Use of water from rivers or } \\
\text { wells in drought-affected areas. }\end{array}$ \\
\hline \multirow{4}{*}{ HM-2 } & \multirow{4}{*}{$\begin{array}{l}\text { Injuries from } \\
\text { hitting } \\
\text { moving parts } \\
\text { of machinery } \\
\text { during } \\
\text { earthwork. }\end{array}$} & $\mathrm{EX}=0$ & \multirow{4}{*}{$\begin{array}{l}\text { Volume of } \\
\text { excavated } \\
\text { and/or filled } \\
\text { material per } \mathrm{m}^{2} \\
\text { of site } \\
\text { occupation } \\
\left(\mathrm{m}^{3} / \mathrm{m}^{2}\right) \text {. }\end{array}$} & $\begin{array}{l}\text { SF } \\
\text { MF }\end{array}$ & $\begin{array}{l}\mathrm{P}=0.0000 \\
\mathrm{P}=0.0000\end{array}$ & & \\
\hline & & $\mathrm{EX}=1$ & & $\begin{array}{l}\mathrm{SF} \\
\mathrm{MF}\end{array}$ & $\begin{array}{l}0.0000<\mathrm{P}<0.4517 \\
0.0000<\mathrm{P}<0.6215\end{array}$ & & \\
\hline & & $\mathrm{EX}=9$ & & $\begin{array}{l}\mathrm{SF} \\
\mathrm{MF}\end{array}$ & $\begin{array}{l}0.4517 \leq \mathrm{P}<5.6733 \\
0.6215 \leq \mathrm{P}<7.1119\end{array}$ & & \\
\hline & & $\mathrm{EX}=25$ & & $\begin{array}{l}\mathrm{SF} \\
\mathrm{MF}\end{array}$ & $\begin{array}{l}\mathrm{P} \geq 5.6733 \\
\mathrm{P} \geq 7.1119\end{array}$ & & \\
\hline
\end{tabular}

${ }^{1}$ Water consumption $\left(\mathrm{m}^{3}\right)=0.2 \cdot \mathrm{Ce}+0.6 \cdot \mathrm{G}+0.1 \cdot \mathrm{Co}$; where $\mathrm{Ce}=$ amount of cement $\left(\mathrm{m}^{3}\right), \mathrm{G}=$ amount of gypsum $\left(\mathrm{m}^{3}\right)$ and Co $=$ amount of concrete $\left(\mathrm{m}^{3}\right)$.

Table 2. Evaluation of environmental impacts and health and safety risks related to the construction process. 
We developed indicators to assess the significance of environmental and health and safety risks in terms of severity, concerns and exposure. These indicators were based on specific observable or measurable characteristics of a construction project and represented the variable that was being measured in all cases. As this model was intended to objectively assess the environmental impacts and construction safety risks in advance, the indicators were always based on information available in the construction project documents (e.g. the building specifications, the drawings, the bill of quantities, the health and safety plan, and the budget). Although quantitative indicators are more desirable, qualitative assessment indicators had to be used when numerical data were not available in the construction project documents. Direct indicators were proposed whenever possible, as they are unequivocal (i.e. RC-1 in Table 2). However, direct indicators were not always available for use in this model, as the assessment was carried out in advance. In such cases, indirect indicators had to be proposed (i.e. HM-2 in Table 2).

To establish significance limits for each of the indicators, we needed to characterize the current performance levels in construction projects. As a starting point, we considered that a high proportion of construction projects involve a moderately significant environmental impact and safety risk. To establish the upper and lower limits for moderately significant environmental impacts and safety risks, we calculated a $68 \%$ confidence interval $[\mu-\sigma, \mu+\sigma]$ for each indicator. Above this threshold, environmental aspects / health and safety risks were considered extremely significant. Below it, they were considered non-significant (Gangolells et al., 2009; Gangolells et al., 2010). Thresholds were defined by means of a statistical analysis of quantitative indicators from 55 new-start residential construction projects. The main data collection technique involved reviewing construction project documents. First, several Excel ${ }^{\circledR}$ spreadsheets were designed to calculate the indicators for each of the 55 construction projects, using the quantitative data available in the documents. Then, in order to calculate corresponding significance limits, numerical values obtained during the assessment of the 55 real new-start construction projects were grouped for each particular indicator in a separate Excel $^{\circledR}$ spreadsheet. The significance limits for indicators expressed in qualitative terms were derived from previous experiences and the assessment scales were described with great care and precision (Table 2). Table 1 in Gangolells et al. (2009) and Table 2 in Gangolells et al. (2011) include indicators and their corresponding significance limits within the environmental domain, whereas Table 2 in Gangolells et al. (2010) lists safety indicators and their corresponding significance limits.

The significance of an environmental impact or health and safety risk in a particular construction project is obtained using the followings expressions:

$$
\begin{aligned}
& S G_{E j}=S V_{j} \cdot C O_{j} \\
& S G_{S j}=E X_{j}
\end{aligned}
$$

where $\mathrm{SG}_{\mathrm{Ej}}$ designates the significance of a particular environmental impact $\mathrm{j}$ in a specific construction project, $\mathrm{SV}_{\mathrm{j}}$ denotes the impact severity, and $\mathrm{CO}_{\mathrm{j}}$ corresponds to the concerns parameter. $\mathrm{SG}_{\mathrm{Sj}}$ designates the significance of a particular safety risk $\mathrm{j}$ in $\mathrm{a}$ specific construction project and $\mathrm{EX}_{\mathrm{j}}$ corresponds to the exposure parameter (Table 2). 
The model assesses the overall environmental impact and safety risk level (R) of a construction project, as shown in (3).

$$
R=R_{E}+R_{S}=\sum_{j=1}^{n} S G_{E j}+\sum_{j=1}^{n} S G_{S j}
$$

where $R_{E}$ is the overall environmental impact level of a construction project and $R_{S}$ is the overall safety risk level of a construction project. Obviously, the construction project with the highest sum has the most significant environmental impact and the lowest safety level.

If the significance of any environmental impact or safety risk is found to be higher than 9, actions must be taken to eliminate or reduce that impact or risk. This limit is the result of considering an intermediate situation for both the environmental domain (a moderately significant impact of secondary concern to all or most interested parties) and the health and safety domain (moderately significant exposure).

\subsection{INTEGRATED OPERATIONAL CONTROL}

A thorough analysis of ISO 14001:2004 and OHSAS 18001:2007 demonstrated high compatibility between the operational control requirements within the environmental and health and safety domains. Both ISO 14001:2004 and OHSAS 18001:2007 first require the identification of key operations and activities that are associated with recognized environmental impacts and health and safety risks. Both norms also require the implementation of documented procedures and work instructions, to ensure that activities are carried out under specified conditions. If environmental impacts and health and safety risks are considered central features within the operational control domain, construction processes represent the link back to their origins, whereas work instructions represent the link to action (Gangolells, 2010). Therefore, efficient integrated environmental and health and safety operational control in construction sites is based on four key concepts (environmental impacts, health and safety risks, construction processes and work instructions) and their corresponding relationships. In this context, the development of an ontology-based approach was considered suitable for several reasons. Ontologies have traditionally helped to represent key concepts and their relationships effectively in a particular subject area (Gangolells, 2010) and they offer a rich conceptualization and a shared reusable representation of domain-wide knowledge (El-Gohary and El-Diraby, 2010). The ontology-based approach was strongly influenced by a method proposed by Noy and McGuiness (2001) and it was first implemented through Protégé 3.4 beta (Gangolells, 2010). The last part of Figure 2 shows the conceptual structure of the ontology-based approach for on-site integrated environmental and health and safety management, including major classes and their corresponding relationships. The ontology was also implemented through a radial browser developed by Stefaner (2009) in order to increase its usability. This interface allows complex concept network structures to be displayed intuitively. The radial browser can visualize which work instructions should be planned to minimize a particular environmental impact or health and safety risk (taking into account possible 
interactions between mitigation measures) and when (i.e. in which construction stage) they should be implemented, among other aspects (Figure 3).

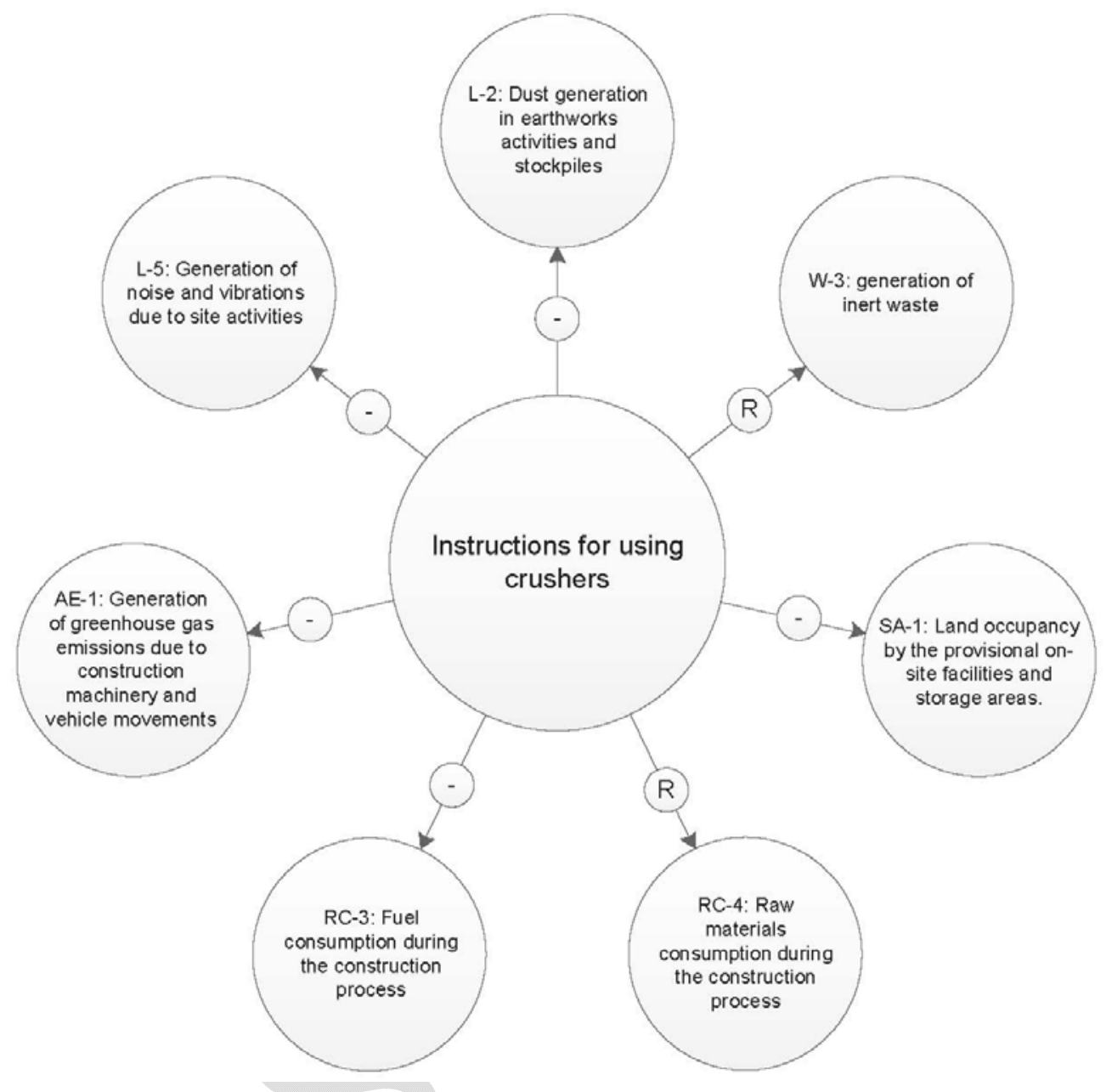

Figure 3. Identification of environmental impacts and health and safety risks related to the work instruction 'instructions for using crushers'.

\section{VALIDATION}

The validation approach is based on Sargent (1998) and includes three steps. The first step is conceptual model validation, which involves determining that the theories and assumptions underlying the conceptual model are correct and reasonable for its purposes (Sargent, 1998). The model was validated by a panel of academic and professional experts from various professional fields with different backgrounds. The panel included two senior project managers working in construction SMEs, two experts from environmental consultancy firms with several years of experience in the construction management field, and two occupational health and safety consultants with extensive experience in the construction sector. The consultation panel was also composed of two associate professors at the Technical University of Catalonia with a broad background in on-site environmental and health and safety management. Experts were asked to answer the following questions "Is the problem situation analysed from 
the appropriate perspective?" and "Is this perspective susceptible to leading to the expected solution?" Based on their positive answers, we can assume that the perspective undertaken for the design of the conceptual model was appropriate and accepted by the final users of the model. Thus, conceptual model validation demonstrated that the model leads to the achievement of solutions for the identified problem.

The second step is data validation, which can be defined as ensuring that the data necessary for model building, evaluation and testing are adequate and correct (Sargent, 1998). Hence, this step assesses reliance on complete, appropriate, accurate and consistent data. In this case, the model was built using data from construction project documents. Indicators were developed and significance limits formulated on the basis of a statistical analysis of several real new-start construction projects. Data sources were specifically checked in Table 1 of Gangolells et al. (2009) and Table 2 of Gangolells et al. (2010), to verify that all the indicators could be extracted from the project documents. In addition, the model is appropriately calibrated to the observed market behaviour, as current performance levels in construction projects were taken as a baseline for formulating the significance limits. We developed data collection and storage procedures to ensure that appropriate and accurate data were used. First, several Excel ${ }^{\circledR}$ spreadsheets were designed to calculate the environmental and health and safety indicators for each construction project. We also drew up several Excel ${ }^{\circledR}$ spreadsheets to calculate significance limits for each indicator. Each spreadsheet grouped the numerical values obtained during the assessment of the 55 real new-start construction projects for a particular indicator. In this way, the collected data were tested using techniques such as internal consistency checks. As in Fellows and Liu (2008), the case study that we selected was a real construction project that had not been used in building the model, to ensure that the data required for the model evaluation and testing were adequate and correct. Thus, the tests were independent.

Finally, the third step includes operational validation, which involves determining that the model's output behaviour has the accuracy required for the intended purpose or applicability of the model (Sargent, 1998). The main attribute that affects operational validity is whether the original system is observable, where observable means that data can be collected on the operational behaviour of the system (Sargent, 1998). According to East et al. (2008), one of the major difficulties in construction research is the lack of test cases on which to verify and validate research results. Construction projects are expensive. Therefore, in most cases it is unfeasible to test design alternatives or other planning strategies. In addition, there are only limited data sets on which construction management research can be based (East et al., 2008). In the case of non-observable systems, the existing literature suggests that the developed model could be compared to other existing models (Sargent, 1998). However, as stated before, no relevant approaches for simultaneously integrating aspects of environmental and health and safety management during the construction design and planning stages were found in the literature. Previous authors also suggest that model behaviour can be assessed by examining the output behaviour using appropriate validation techniques (Sargent, 1998). Such techniques usually include parameter variability-sensitivity analysis (Sargent, 1998), which consists of changing the values of the model input to determine the effect on the behaviour of the model and its output. In this case, the proposed model was validated by applying it in two construction SMEs (Gangolells, 2010). We report 
here the application of the model in one of the construction SMEs to illustrate the practical use of the model during the design and planning stages of a multi-family construction project and to demonstrate its benefits.

\subsection{CASE STUDY}

The model was implemented in a small construction company that did not have a certified management system but was interested in one. In fact, the company had already taken the first steps towards introducing an integrated environmental and safety management system, but the uncertainty caused by the inherent peculiarities of construction projects hampered the full implementation. The main concerns were related to the identification and assessment of environmental aspects and safety risks during the pre-construction stage. Clear incentives for adopting integrated management systems were avoidance of duplicate tasks and inconsistencies.

First, the existing company's environmental and safety policy was revised. Then, the process of identifying and assessing environmental aspects and safety risks was agreed at top management level and it was formally stated in the documentation. The construction company's existing work instructions were semantically matched to those in the developed model. The implementation team also had to add some missing work instructions. Finally, the model was applied to a new residential construction project and two different approaches were examined. The first approach provided the basis for making informed design decisions. The second approach provided an objective assessment of the remaining potential environmental impacts and health and safety risks after the design process. Then, the model provided useful advice for the construction phase, allowing the construction company to optimize its on-site environmental and safety performance.

In this case, initial requirements included designing a detached four-storey building containing 19 dwellings and an underground car park with a total floor area of 2,241 $\mathrm{m}^{2}$. Located in a non-protected rural area with a nearby natural riverbed, the nearest neighbouring town centre is less than 1,000 m away. As part of the first approach and during the design stage, several design alternatives related to the concrete structure of the building and its façades were evaluated (Table 3 ). Data was collected by revising the construction project documents according to Table 1 in Gangolells et al. (2009), Table 2 in Gangolells et al. (2011) and Table 2 in Gangolells et al. (2010). The model enabled us to conclude that, in this case, the precast concrete structure had best on-site environmental and health and safety performance than the in-situ concrete structure. The best performance was also for precast concrete façades (Table 3).

\begin{tabular}{|l|c|c|}
\hline Design alternatives & $\begin{array}{c}\text { Overall Safety Risk } \\
\text { Level }\end{array}$ & $\begin{array}{c}\text { Overall Environmental } \\
\text { Impact Level }\end{array}$ \\
\hline In-situ concrete structure & 108 & 41 \\
Precast concrete structure & 36 & 28 \\
\hline Facing brick* & 133 & 48
\end{tabular}




\begin{tabular}{|l|c|c|}
\hline Design alternatives & $\begin{array}{c}\text { Overall Safety Risk } \\
\text { Level }\end{array}$ & $\begin{array}{c}\text { Overall Environmental } \\
\text { Impact Level }\end{array}$ \\
\hline Masonry walls with natural stone cladding* & 116 & 24 \\
$\begin{array}{l}\text { Masonry walls with single-layer mortar } \\
\text { coating* }\end{array}$ & 75 & 33 \\
Precast concrete facades* & 49 & 8 \\
\hline
\end{tabular}

* In the case of dry partition walls.

Table 3. Overview of the assessment of the environmental and health and safety related performance of a construction project, depending on different design alternatives for a multi-family dwelling.

Based on the assessment results and the clients' preferences, the final proposal was a precast concrete structure and masonry walls with natural stone cladding. The building has a gable roof and windows for ventilation. The $502.36 \mathrm{~m}^{2}$ underground floor has 19 parking places and an engine room. The $460 \mathrm{~m}^{2}$ ground floor and the $541.92 \mathrm{~m}^{2}$ first floor include 6 dwellings each. Two of them have an entrance hall, a kitchen-diningliving room, a toilet, a bathroom, a laundry room, three bedrooms and a private garden. The remaining four dwellings are smaller, with only two bedrooms. The $541 \mathrm{~m}^{2}$ second floor and the $194 \mathrm{~m}^{2}$ third floor include 7 duplex apartments with a similar structure to the others. Masonry bricks with a plastered finish were used to build almost all of the internal partitions. The ceilings have a plastered finish, whereas the floor is made from natural wood. Kitchen, bathrooms and toilets are completely tiled and have false ceilings. The windows are made of aluminium and the balconies have wooden railings. During the planning stage, all provisional on-site facilities and storage areas were planned to be inside the construction site perimeter without affecting the amount of free space for vehicle or pedestrian circulation or the number of available parking places. Water and electricity networks were available at the construction site. No use of special machinery was planned and construction work was expected to be carried out during daytime hours.

As part of the second approach and after the assessment, 4 construction safety risks and 10 environmental impacts were found to be significant. The model also highlighted some other significant risks that apply to the environmental and health and safety domains. These included risks L-1 (dust generation in activities with construction machinery and transport), L-2 (dust generation in earthworks activities and stockpiles) and L-3 (dust generation in activities with cutting operations), which are classified in the environmental category of 'local issues' but are also in the safety category of 'contact with chemical agents'. Risk AC-1 (fires in areas for storing flammable and combustible substances) was also found to be significant. This risk belongs to the environmental category of 'incidents, accidents and potential emergency situations' and to the safety category of 'fires and explosions'.

Once the relevance of L-2 (dust generation in earthwork activities and stockpiles) had been identified and after reviewing the ontology-based approach, the construction team identified 19 work instructions that could be implemented on-site to minimize its 
potential harmful effects (i.e. instructions for wetting vehicles and machinery passageways, instructions for using protective masks, instructions for handling and storing dusty materials, etc.). The construction team also realized that the implementation of some work instructions that are specifically focused on other environmental impacts or health and safety risks may have a negative or a positive effect on L-2. For example, instructions for using crushers may increase the significance of L-2, whereas instructions for managing complaints may be beneficial for L-2. According to Figure 3, 'instructions for using crushers' clearly reduces the environmental impacts WG-3 (generation of inert waste) and RC-4 (raw materials consumption during the construction process). Thus, the construction team identifies the advantages and disadvantages of implementing a work instruction for using crushers. The construction team checks which construction processes may cause a particular environmental impact or health and safety risk. Construction processes related to L-2 include earthworks, waste management, pavements, etc. Thus, the construction team identifies when to implement the corresponding on-site work instructions. Finally, the construction team checks which environmental impacts and health and safety risks are related to a particular construction process. Having identified the construction processes with the most significant environmental impacts and health and safety risks, this model is used to help the construction team to plan the timing and frequency of inspections.

\section{CONCLUSIONS}

The main contribution of this innovative research to the body of knowledge is the development of a process-oriented model to enhance the integration of environmental and safety management systems in construction companies, beyond the mere combination of documentation. As this system establishes the basis and criteria required to identify, assess and operationally control environmental impacts and health and safety risks at project level, it contributes to reducing the existing level of uncertainty related to the integration of planning and control instruments, which is widely recognized by the existing literature as a major implementation barrier.

The model is applied during the planning stage of the implementation of an integrated environmental and health and safety management system and allows to identify, assess and control environmental impacts related to the execution of a construction project and corresponding health and safety implications for construction workers and the surrounding population. The strength of this model lies in the following facts: (1) it is the first attempt towards simultaneously integrating potential on-site environmental impacts and health and safety risks and construction workers' safety in the design and construction and planning stages; (2) it provides a comprehensive overview of the expected on-site environmental and safety performance of a construction project; (3) it highlights significant environmental impacts and health and safety risks during the preconstruction stage in an objectively manner; and (4) it provides on-site guidance to eliminate the remaining impacts and risks or reduce them to an acceptable level.

The findings of this study have direct implications for designers as the model helps to explicitly consider on-site environmental impacts and construction worker safety during the design process. Designers can compare alternatives during the design phase and 
determine the corresponding overall environmental impact and safety risk levels of a construction project, without their creative talents being restricted. The model is especially useful for less-experienced designers who lack the skills and knowledge required to recognize environmental aspects and safety hazards in the development of optimal designs. The development of an environmentally friendly and safer design solution during the design phase reduces the time and money spent on potential incidents or accidents during the construction stage.

Similarly, the developed model has direct implications for construction companies by highlighting remaining potential environmental impacts and health and safety risks after the design process. Improved identification of significant environmental impacts and safety risks undoubtedly leads to successful on-site management. A range of measures can then be implemented on the construction site to eliminate the remaining impacts and risks or reduce them to an acceptable level. This research proposes an ontology-based approach to promote the integrated operational control of on-site environmental impacts and health and safety risks. An understanding of the relationships between environmental impacts, health and safety risks, construction processes and work instructions helps contractors to manage and control these factors.

Lessons learned during the application of the developed model demonstrate that integrated environmental and safety management systems can be enhanced easily in construction SMEs by focusing on the sub-systems for identifying, assessing and operationally controlling environmental aspects and health and safety hazards and using a risk analysis based approach. However, the present study has certain limitations that need to be taken into account. Firstly, the application of the model is demonstrated only through two case studies and, secondly, the model is drawn from the European context. Nevertheless, the findings from this research could be a useful reference for studying similar topics in other countries. For example, instead of providing a standard set of environmental aspects and health and safety risks, the model proposes an exhaustive preliminary analysis with a process-oriented approach. In this way, by including other construction techniques and systems, environmental impacts and health and safety risks can be tailored to regional specificities. Significance limits for environmental and health and safety indicators have been obtained assuming as a baseline the 'typical' or 'average' performance levels in European construction projects. Therefore, significance limits corresponding to developed indicators might not accurately reflect the construction practices that are widespread in other countries. However, by following the suggested approach, significance limits can also be tailored to regional specificities. Further research is needed to reduce the time required to assess each construction design. Time and effort can be saved by importing the required data from the tools the designer normally uses in the design process (i.e., all the data related to the bill of quantities can be imported automatically from the Building Information Models). Taking into account that Building Information Models are likely to play a significant role in the future of the architecture, engineering and construction industries, importing data from them would maximize the usefulness of the developed model as a design tool. 


\section{REFERENCES}

Baxendale, T., and Jones, O. (2000). "Construction design and management safety regulations in practice - progress on implementation." International Journal of Project Management, 18(1), 33-40.

Bhutto, K., Griffith, A., and Stephenson, P. (2004). "Evaluation of Quality, Health and Safety and Environment Management Systems and their Implementation in Contracting Organizations." COBRA 2004, The International Construction Research Conference of the Royal Institution of Chartered Surveyors, Leeds, UK.

Bunz, K. R., Henze, G.P., Tiller, D.K. (2006). "Survey of Sustainable Building Design Practices in North America, Europe, and Asia." Journal of Architectural Engineering, 12(1), 33-62.

Cameron, I., and Hare, B. (2008). "Planning tools for integrating health and safety in construction." Construction Management and Economics, 26(9), 899-909.

Camino, M. A., Ritzel, D. O., Fontaneda, I. and González, O. J. (2008). "Construction industry accidents in Spain". Journal of Safety Research, 39(5), 497-507.

Carter, G., and Smith, S. D. (2001). "Construction Safety Risk - Improving the Level of Hazard Identification." ESREL 2001, European Safety \& Reliability International Conference, Turin, Italy.

Carter, G., and Smith, S. D. (2006). "Safety hazard identification on construction projects." Journal of Construction Engineering and Management, 132(2), 197-205.

Chen, Z., Li, H., and Wong, C. T. C. (2000). "Environmental management of urban construction projects in China." Journal of Construction Engineering and Management, 126(4), 320-324.

Chen, Z., Li, H., and Hong, J. (2004). "An integrative methodology for environmental management in construction." Automation in Construction, 13(5), 621628.

Chen, Z., Li, H., and Wong, C. T. C. (2005). "EnvironalPlanning: Analytic network process model for environmentally conscious construction planning." Journal of Construction Engineering and Management, 131(1), 92-101.

Chen, Z., and Li, H. (2006). "Environmental management in construction: a quantitative approach.” Taylor \& Francis, UK.

Cheung, S.O., Cheung, K. K. W., and Suen, H.C.H. (2004a). "CSHM: Webbased safety and health monitoring system for construction management." Journal of Safety Research, 35(2), 159-170.

Cheung, S. O., Tam, C. M., Tam, V., Cheung, K., and Suen, H. (2004b). "A web-based performance assessment system for environmental protection: WePass." Construction Management and Economics, 22(9), 927-935.

Dione, S., Ruwanpura, J. Y., and Hettiaratchi, J. Y. (2005). "Assessing and managing the potential environmental risks of construction projects." Practice Periodical on Structural Design and Construction, 10(4), 260-266.

East, E. W., Kirby, J. G., and Liu, L.Y. (2008). "Verification and validation of a project collaboration tool." Automation in Construction, 17(2), 201-214.

El-Gohary, N. M., and El-Diraby, T. E. (2010). "Domain ontology for processes in infrastructure and construction." Journal of Construction Engineering and Management, 136(7), 730-744.

Eom, C. S. J., and Paek, J. H. (2009). "Risk index model for minimizing environmental disputes in construction." Journal of Construction Engineering and Management, 135(1), 34-41. 
European Commission [on-line]. "EMAS - The European Eco-Management and Audit Scheme." <http://www.emas-register.eu> (Sep. 8, 2010).

Fellows, R., and Liu, A. (2008). "Research methods for construction." WileyBlackwell, Oxford.

Frijters, A. C. P., and Swuste, P. H. J. J. (2008). "Safety assessment in design and preparation phase." Safety Science, 46(2), 272-281.

Gambatese, J. A. (2008). "Research issues in Prevention through Design." Journal of Safety Research, 39(2), 153-156.

Gangolells, M., Casals, M., Gassó, S., Forcada, N., Roca, X., and Fuertes, A. (2009). "A methodology for predicting the severity of environmental impacts related to the construction process of residential buildings." Building and Environment, 44(3), 558-571.

Gangolells, M., Casals, M., Forcada, N., Roca, X., and Fuertes, A. (2010). "Mitigating construction safety risks using prevention through design." Journal of Safety Research, 41(2), 107-122.

Gangolells, M. (2010). "Contributions to the implementation of integrated environmental and health and safety management systems in construction companies." Doctoral dissertation, Technical University of Catalonia, Spain < http://tdx.cat/handle/10803/77920> (Feb. 22, 2012).

Gangolells, M., Casals, M., Gassó, S., Forcada, N., and Roca, X. (2011). "Assessing concerns of interested parties when predicting the significance of environmental impacts related to the construction process of residential buildings." Building and Environment, 46(5), 1023-1037.

Griffith, A. (2011). "Integrated management systems for construction: quality, environment and safety." Prentice Hall, UK.

Griffith, A., and Bhutto, K. (2008a). "Contractor's experience of integrated management systems." Management, Procurement and Law, 161(3), 93-98.

Griffith, A., and Bhutto, K. (2008b). "Improving environmental performance through integrated management systems (IMS) in the UK." Management of Environmental Quality, 19(5), 565-578.

Imriyas, K. (2009). "An expert system for strategic control of accidents and insurers' risks in building construction projects." Expert Systems with Applications, 36(2), 4021-4034.

ISO Central Secretariat (2009). "The ISO Survey of Certifications 2008." Switzerland.

$\mathrm{ITeC}$

[on-line].

"Metabase

database."

$<$ http://www.itec.es/noubedec.c/bedec.aspx $>$ (Sep. 25, 2006).

Jørgensen, T. H., Remmen, A., and Mellado, M. D. (2006). "Integrated management systems - three different levels of integration." Journal of Cleaner Production, 14(8), 713-722.

Karapetrovic, S. (2002). "Strategies for the integration of management systems and standards." The TQM Magazine, 14(1), 61-67.

Koehn E., and Datta, N. K. (2003). "Quality, Environmental, and Health and Safety Management Systems for Construction Engineering”. Journal of Construction Engineering and Management, 129(5), 562-569.

Labodová, A. (2004). "Implementing integrated management systems using a risk analysis based approach." Journal of Cleaner Production, 12(6), 571-580. 
Li, S., Shen, Y., and Zhang, Z. (2005). "A new quantitative framework of environmental performance assessment applicable to construction stage." International Conference on Constructions \& Real Estate Management, "The Challenge of Innovation", Pengang, Malaysia.

Noy, N., and McGuiness, D. L. (2001). "Ontology Development 101: A guide to Creating your First Ontology." Stanford Knowledge Systems Laboratory, Technical Report KSL-01-05 and Stanford Medical Informatics, Technical Report SMI-20010880.

OHSAS Project Group [on-line]. "Results of the survey into the availability of OH\&S Standards and Certificates, up until 2007-12-31." $<$ http://elsmar.com/Forums/attachment.php?attachmentid=13033\&d=1281112639> (Sep 8, 2010).

Piñeiro, P., and García, J. M. (2007). "Particularidades de los sistemas de gestión medioambiental en las empresas constructoras. Principales dificultades en su implantación." Contabilidad y Auditoría, 13(25), 109-132.

Pheng, L. S., and Shiua, S. C. (2000). "The maintenance of construction safety: riding on ISO 9000 quality management systems." Journal of Quality in Maintenance Engineering, 6(1), 28-44.

Pheng, L. S., and Pong, C. Y. (2003). "Integrating ISO 90001 and OHSAS 18001 for Construction." Journal of Construction Engineering and Management, 129(3), 338-347.

Pheng, L. S., and Tan, J. H. K. (2005). "Integrating ISO 9001 Quality Management System and ISO 14001 Environmental Management System for Contractors." Journal of Construction Engineering and Management, 131(11), 12411244.

Pheng, L. S., and Kwang, G. K. (2005). "ISO 9001, ISO 14001 and OSHAS 18001 management systems: integration, costs and benefits for construction companies." Architectural Science Review, 48(2), 145-152.

Roberts, H., and Robinson, G. (1998). "ISO 14001 EMS implementation handbook." Butterworth-Heinemann, Oxford.

Salomone, R. (2008). "Integrated management systems: experiences in Italian organizations." Journal of Cleaner Production, 16(16), 1786-1806.

Sargent, R. (1998). "Verification and validation of simulation models." Proceedings of the 1998 Winter Simulation Conference, Syracuse, USA.

Saurin, T. A., Formoso, C. T., and Guimaraes, L. B. M. (2004). "Safety and production: An integrated planning and control model." Construction Management and Economics, 22(2), 159-169.

Seo, J. W., and Choi, H. H. (2008). "Risk-based safety impact assessment methodology for underground construction projects in Korea." Journal of Construction Engineering and Management, 134(1), (2008) 72-81.

Shen, L. Y., Lu, W. S., Yao, H., and Wu, D. H. (2005). "A computer-based scoring method for measuring the environmental performance of construction activities." Automation in Construction, 14(3), 297-309.

Stefaner, M. [on-line]. "Relation browser." $<\mathrm{http}$ ://moritz.stefaner.eu/projects/relation-browser/> (Jan. 11, 2009).

Tam, C. M., Tam, V. W. Y., and Tsui, W. S. (2004). "Green construction assessment for environmental management in the construction industry of Hong Kong." International Journal of Project Management, 22(7), 563-571. 
Tam, V. W. Y., Tam, C. M., Zeng, S. X., and Chan, K. K. (2006). "Environmental performance measurement indicators in construction." Building and Environment, 41(2), 164-173.

Trethewy, R. W., Atkinson, M., and Falls, B. (2003). "Improved Hazard Identification for Contractors in the Construction Industry." Journal of Construction Research, 4(1), 71-85.

Wang, W., Liu, J., and Chou, S. (2006). "Simulation-based safety evaluation model integrated with network schedule." Automation in Construction, 15(3), 341-354.

Zeng, S. X., Tian, P., and Shi, J. (2005). "Implementing integration of ISO 9001 and ISO 14001 for Construction." Managerial Auditing Journal, 20(4), 394-407.

Zeng, S. X., Shi, J. J., and Lou, G.X. (2007). "A synergetic model for implementing an integrated management system: an empirical study in China." Journal of Cleaner Production, 15(18), 1760-1767.

Zeng, S. X., Tam, V. W. Y., and Tam, C. M. (2008). "Towards occupational health and safety systems in the construction industry of China." Safety Science, 46(8), 1155-1168.

Zutshi, A. (2005). "Integrated management system. The experiences of three Australian organizations." Journal of Manufacturing Technology, 16(2), 211-232. 